Volume 5 Number 1, January-June 2021: pg. 39-52.

Fakultas Hukum, Universitas Lampung,

Bandar Lampung, Lampung, Indonesia. E-ISSN: 2598-3105 P-ISSN: 2723-2581 http://jurnal.fh.unila.ac.id/index.php/cepalo

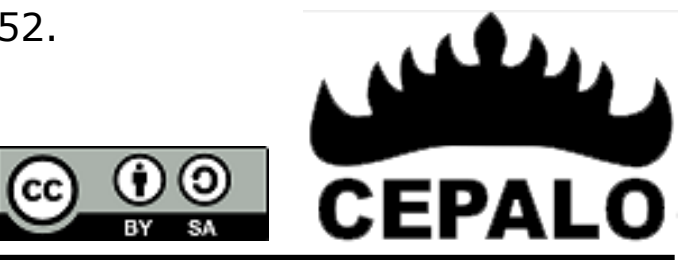

\title{
THE RECONSTRUCTION OF THE CRIMINAL JUSTICE SYSTEM FOR ADDRESSING CORRUPTION CRIME IN THE FRAMEWORK OF SUPPORTING NATIONAL DEVELOPMENT
}

\author{
Maroni $^{1}$, Nenny Dwi Ariani ${ }^{2}$, Dheka Ermelia Putri ${ }^{3}$ \\ ${ }^{1}$ Faculty of Law, Universitas Lampung, Email: maroniunila@gmail.com \\ ${ }^{2}$ Faculty of Law, Universitas Lampung, Email: nennydwiariani@gmail.com \\ ${ }^{3}$ Faculty of Law, Universitas Lampung, Email: ermeliadheka@gmail.com
}

Submitted: February 1, 2021; Reviewed: March 1, 2021; Accepted: March 3, 2021

DOI: 10.25041/cepalo.v5no1.2231

\begin{abstract}
The urgency for criminal justice system reconstruction of the corruption is given the legal gap in eradicating corruption law if it is only carried out by the Regional Corruption Court, which is domiciled in the Capital Province. Because the Corruption Court's working area is so broad, it is because many corruption cases to be tried, it will also require large fees and a large number of judges, and ideally, it will take a long time in the process of examining. Meanwhile, on the other hand, there is an obligation for the corruption case settlement by the Corruption Court to be carried out quickly, simply and at low cost. This paper's problems are: (a) Why is it important to reconstruct the Corruption Criminal Justice System? (b) What is the ideal construction of the Corruption Criminal Justice System to support national development in Indonesia? The research method is qualitative with juridical normative and sociological approaches, especially in collecting primary data to reconstruct the corruption criminal justice system.
\end{abstract}

This research shows that the ideal construction of the corruption court system is to support National Development, namely the relative competence of the Regional Corruption Court, which is not limited by the administrative area of a province. The Republic of Indonesia's administrative area consists of various Provinces and Regencies/Cities. In these conditions, ideally, the relative competence of a Corruption Court can also examine corruption cases in districts/cities close to the Corruption Court, even though they are located in a different province from the domicile of a Corruption Court.

Keywords: Corruption, Court, Reconstruction. 


\section{A. Introduction}

Corruption is an extraordinary crime because the crime method used sophisticated and varied tools, such as professional technology, authority or position manipulation and another tool. ${ }^{l}$ One of the corruption impacts is suffering people; corruption has hindered national development activities and various government programs from improving the Indonesian people's welfare. $^{2}$

Thus, eradicating corruption needs to be increased from time to time, both in quality and quantity. ${ }^{3}$ Corruption eradication must be carried out comprehensively and in an extraordinary way. It can no longer be done by using conventional or counter crime eradication methods, such as theft, fraud and bribery as regulated in the Criminal Code (KUHP) and Criminal Procedure Law (KUHAP). That's why Indonesia need Special Corruption Criminal Court System.

The Indonesian people's efforts in the context to increase the eradication of corruption are manifested in the form of renewing aspects of legal substance and legal structure. Renewal of the legal substance aspect by amending the law on corruption was initially based on Law Number 3 of 1971 being replaced by Law Number 31 of 1999 and Law Number 20 of 2001 concerning Eradication of Corruption Crime (Corruption Law). ${ }^{4}$ Based on this law, both the aspects of action, responsibility and sanctions of corruption has a large transformation than the previous law.

Meanwhile, from the aspect of the legal structure includes legal institutions, a Corruption Eradication Commission (KPK) has been established based on Law Number 30 of 2002 concerning the Corruption Eradication Commission (KPK Law) ${ }^{5}$, which has duties an investigator and general prosecutor of corruption with nominal value is more from one billion rupiahs. In addition, Corruption Court (Tipikor Court) has also been established based on Law Number 46 of 2009 concerning the Corruption Court (Law of Corruption Court). ${ }^{6}$ It is a Special Court located within the General Court and the only court with authority to judge Indonesia's corruption case. ${ }^{7}$

The Corruption Court's existence is very important in eradicating corruption because to increase the efficiency and effectiveness of law enforcement against corruption. ${ }^{8}$ It is also to remember the court's examination stage in the evidence process based on the law by the judge to determine the guilt of defendant's, so he can be held responsible for the crime that he already did.

\footnotetext{
${ }^{1}$ Ifrani Fakultas et al., "TINDAK PIDANA KORUPSI SEBAGAI KEJAHATAN LUAR BIASA," Al-Adl: Jurnal Hukum 3, no. 3 (2017): 319-36, 321, DOI: 10.31602/al-adl.v9i3.1047.

2 La Sina, "DAMPAK DAN UPAYA PEMBERANTASAN SERTA PENGAWASAN KORUPSI DI INDONESIA," Jurnal Hukum Pro Justitia 26, no. 1 (2008): 39-51, 43.

${ }^{3}$ T. W. Tri Widiastuti, "KORUPSI DAN UPAYA PEMBERANTASANNYA," Jurnal Wacana Hukum 8, no 2 (2009): 107-118, 108, DOI: 10.33061/1.JWH.2009.8.2.317.

${ }^{4}$ Imanuel Arung Tiku, "KAJIAN YURIDIS TERHADAP TINDAK PIDANA KORUPSI," Lex Crimen 9, no. 2, (2020): 1-20, 5.

${ }^{5}$ R Nazriyah, "KEWENANGAN KOMISI PEMBERANTASAN KORUPSI DALAM PENYIDIKAN KASUS SIMOLATOR SIM (KAPOLRI VS KPK)," Jurnal Hukum Ius Quia Iustum 19, no. 4 (2012): 586-606, 591.

6 Mudzzakir, "PENGADILAN TINDAK PIDANA KORUPSI: TINDAK PIDANA BIASA PENANGANANNYA LUAR BIASA (CORRUPTION COURT: COMMON CRIME WITH EXTRAORDINARY REDUCTION)", Jurnal Legislasi Indonesia 8, no. 2, (2011): 297-320, 297.

${ }^{7}$ Maroni, Pemberantasan Korupsi Berbasis Hukum Pidana Progresif (Bandar Lampung: Universitas Lampung, 2011), 11.

${ }^{8}$ Muhammad Afif, "EKSISTENSI PENGADILAN TINDAK PIDANA KORUPSI DI INDONESIA DALAM PENEGAKAN HUKUM TINDAK PIDANA KORUPSI DI INDONESIA", Ensiklopedia of Journal 1, no. 1 (2018): 97-106, 103.
} 
The Corruption Court must be conducted by a panel of judges consisting of 2 (two) regular district court judges and 3 (three) ad hoc judges. ${ }^{9}$ Based on Article 3 of the Corruption Court Law, the Corruption Court is located in each district/capital city which jurisdiction covers the jurisdiction of the district court concerned. ${ }^{10}$ However, during the transitional period based on the provisions of Article 35 Paragraph (1) and Paragraph (2) of the Corruption Court Law, it was stated that for the first time, a Corruption Court was established in every district court in the capital province. Meanwhile, the legal area covers the province's legal area. ${ }^{11}$

The implementation of that provisions, the Decree of the Supreme Court Chief Number 022 / KMA / SK / II / 2011 dated February 7 2011, 14 (fourteen) Regional Corruption Courts were established. ${ }^{12}$ The Regional Corruption Court includes the Medan District Court (PN), Palembang District, Tanjungkarang District, Serang District Court, Yogyakarta District Court, Banjarmasin District, Pontianak District Court, Samarinda District Court, Makassar District Court, Mataram District, Kupang District and Jayapura District Court. Simultaneously, the previous Corruption Courts were the Central Jakarta District Court, the Bandung District Court, the Semarang District Court and the Surabaya District Court. Corruption Court at the Tanjung Karang District covers the entire Lampung Province. ${ }^{13}$ However, it has been more than 17 (seventeen) years that this law's mandate has not yet been realized. Therefore it is proper to rearrange (reconstruct) the existence of the Corruption Court.

The urgency for reconstruction is given the legal gap in eradicating corruption law if it is only carried out by the Regional Corruption Court, which is domiciled in the Capital Province. It is because the working area of the Corruption Court is so wide, it is because many corruption cases to be tried, it will also require large fees and a large number of judges, and ideally, it will take a long time in the process of examining. Meanwhile, on the other hand, there is an obligation for the corruption case settlement by the Corruption Court to be carried out quickly, simply and at low cost. For example, it can be seen by the data in the Tanjungkarang PN Corruption Court in the last 5 (five) years from 2014 to 2018, 305 (three hundred and five) corruption cases were filed by the Lampung Attorney General's Office and various Attorneys in Lampung province. There were 77 cases from the Bandar Lampung Prosecutor's Office and the Lampung High Court, while the cases filed by various Attorneys from external Bandar Lampung were 228 cases. ${ }^{14}$

The existence of the Regional Corruption Court in the capital province currently received criticism from the public. For example, corruption cases in Merauke handled by the Tipikor Court in Jayapura. It has cost a lot of money. So there needs reconsideration Corruption Court existence in the regions with high-cost considerations. ${ }^{15}$ The example is also in Lampung Province, such as the corruption in Liwa, West Lampung Regency, which must

\footnotetext{
${ }^{9}$ General Explanation of Law Number 46 of 2009 concerning Corruption Court.

${ }^{10}$ Fitriati, “ANALISIS PERKEMBANGAN SISTEM PERADILAN PIDANA DITINJAU DARI PERSPEKTIF PENGADILAN TINDAK PIDANA KORUPSI," Yustisia Jurnal Hukum 3, no. 3 (2019): 73-81, 75, DOI: 10.20961/YUSTISIA.V3I3.29550.

11 H. Nurdin, "EKSISTENSI HAKIM AD HOC PADA PENGADILAN TINDAK PIDANA KORUPSI DALAM SISTEM KEKUSAAN KEHAKIMAN," Meraja Journal 2, no. 2 (2019): 167-83, 177, DOI: 10.33080/mrj.v2i2.57.

12 Davit Rahmadan, Sulaiman Fakhrur Razi, "EFEKTIFITAS PERADILAN TINDAK PIDANA KORUPSI DALAM PEMBERANTASAN KORUPSI DI PENGADILAN NEGERI PEKANBARU," Al Hurriyah : Jurnal Hukum Islam 2, no. 2 (2017): 137-148, 141, DOI: 10.30983/alhurriyah.v2i2.409.

${ }^{13}$ Maroni, Loc.Cit., 11.

${ }^{14}$ Registration of Corruption Cases at Tanjungkarang District Court 2014-2018.

15 www.beritasatu.com/hukum/101558-dua-tahun-pengadilan-tipikor-daerah-tren-vonis-ringan-meningkat.html, accessed on May 16, 2020.
} 
be tried at the Corruption Court at the PN. Tanjung Karang is hundreds of kilometres away and takes a long time to reach Bandar Lampung.

The Regional Corruption Court's effectiveness can be measured by one indicator in the effectiveness of the criminal justice system, namely the level of speed of handling a case, of course, with a quality decision. The high-quality decision has the result of an unhurried process of examining witnesses and defendants (chase broadcast). The Regional Corruption Court's effectiveness can be seen from the speed of examination of corruption cases by the predetermined time. The speed in handling a corruption case is in line with one of the aims of holding a special court for corruption, namely to increase the efficiency and effectiveness of law enforcement against corruption. ${ }^{16}$ There is a change in the criminal law politics in tackling corruption based on the Corruption Law as a tool to support national development and realise the whole Indonesian people with just, prosperous, welfare and safe based on Pancasila and the 1945 Constitution. ${ }^{17}$

This paper's legal issue is the size of the Regional Corruption Court working area, which is the same as the provincial administrative area, while its position is in the provincial capital. The effectiveness of the Regional Corruption Court is questioned both from its position as part of the corruption criminal justice system and the operation of various law enforcement agencies in the corruption criminal justice system. The importance of speed in handling a case, according to Ishikawa, delay of justice is denied justice. ${ }^{18}$ In addition, there is a mandate in Article 2 Paragraph (4) of Law Number 48 the Year 2009 concerning Judicial Powers that the Judiciary is simple, quick, and at low cost. ${ }^{19}$

This paper's problems are: (a) Why is it important to reconstruct the Corruption Criminal Justice System? (b) What is the ideal construction of the Corruption Criminal Justice System to support national development in Indonesia? The research method is qualitative with juridical normative and sociological approaches, especially in collecting primary data to reconstruct the corruption criminal justice system. The field research location was in the jurisdiction of the Corruption Crime Court at the Class IA Tanjungkarang District Court.

\section{B. Discussion}

\section{The Urgency to Reconstruct the Corruption Court System}

One of the Indonesian efforts in the corruption eradication effectiveness is establishing a Corruption Court based on Law Number 46 of $2009 .{ }^{20}$ The Corruption Court is the only court with authority to examine, hear and decide corruption cases as regulated in Article 5 of the Corruption Law. ${ }^{21}$ Furthermore, based on Article 3 Corruption Law's provisions, the Corruption Court is located in each district/city capital which jurisdiction covers the jurisdiction of the district court concerned. Meanwhile, according to Article 35 Paragraph (1) and Paragraph (2) of the Corruption Law, it is the first time a Corruption Court is established

\footnotetext{
${ }^{16}$ General Explanation of Law Number 30 of 2002 concerning the Corruption Eradication Commission.

${ }^{17}$ General Explanation of Law Number 30 of 2002 concerning the Corruption Eradication Commission.

18 Ibid., 6.

${ }^{19}$ Nia S. Sihotang, "PENERAPAN ASAS SEDERHANA, CEPAT DAN BIAYA RINGAN DI PENGADILAN NEGERI PEKANBARU BERDASARKAN UNDANG-UNDANG NOMOR 48 TAHUN 2009 TENTANG KEKUASAAN KEHAKIMAN." Jurnal Online Mahasiswa Fakultas Hukum Universitas Riau 3, no. 2 (2016): 1$15,2$.

20 Imron Safii, "URGENSI PENGADILAN TINDAK PIDANA KORUPSI DALAM MEWUJUDKAN PERADILAN YANG BERSIH DAN BERWIBAWA,” Pandecta: Research Law Journal 9, no. 1 (2014): 7691, 77, DOI: 10.15294/pandecta.v9i1.2999.

${ }^{21}$ Nur Mauliddar, Mohd. Din, and Yanis Rinaldi, "GRATIFIKASI SEBAGAI TINDAK PIDANA KORUPSI TERKAIT ADANYA LAPORAN PENERIMA GRATIFIKASI,” Kanun Jurnal Ilmu Hukum 19, no. 1 (2017): 155-173,157.
} 
in every district court in the capital province. Meanwhile, the legal area covers the province's legal area. However, it has been more than ten years since the Corruption Court Law mandate in every district/city capital has not been implemented.

The Tipikor Court's effectiveness as a sub-system of the criminal justice system can be seen from various indicators of the criminal justice system effectiveness. According to Hiroshi Ishikawa, the indicators of the criminal justice system effectiveness are: (a) How long the extent of the clearance rate conducted by the Police; (b) How far the prosecutor succeeded in proving the indictment in court (conviction rate); (c) How long the extent of the handling case speed in the criminal justice system (speedy trial); (d) How long the perpetrator has been reconviction (reconviction rate); (e) How long the extent has the level of public participation in the criminal justice system been carried out. ${ }^{22}$

The operation of the Corruption Court PN IA Tanjung Karang is based on the Decree of the Supreme Court Chief Number: 022 / KMA / SK / II / 2011 dated February 7, 2011. It can be seen through the policy for resolving every corruption case that has occurred in Lampung Province. From 2014 to 2018, the number of corruption cases examined and judged by the Corruption Court PN IA Tanjung Karang is 305 (three hundred and five) cases from various Regional and High Attorneys in Lampung Province, as illustrated in table 1 below.

Table 1: List of the Number of Corruption Cases in the PN Tanjung Karang at 2014 - 2018

\begin{tabular}{|l|c|c|c|c|c|c|}
\hline \multirow{2}{*}{ Location } & \multicolumn{5}{|c|}{ Year } & \multirow{2}{*}{ Total } \\
\cline { 2 - 6 } & 2014 & 2015 & 2016 & 2017 & 2018 & \\
\hline Bandar Lampung & 12 & 19 & 16 & 24 & 6 & 77 \\
\hline Luar Bandar Lpg & 61 & 45 & 38 & 41 & 43 & 228 \\
\hline Total & 73 & 64 & 54 & 65 & 49 & 305 \\
\hline
\end{tabular}

Source: PN Tanjung Karang data processed in 2019

Based on table 1, it can be seen that during the last 5 (five) years from 2014 to 2018, the number of corruption cases examined and judged by the Corruption Court PN IA Tanjungkarang is 305 (three hundred and five) cases consisting of 77 (seventy-seven) cases from Bandar Lampung and as many as 228 (two hundred twenty-eight) cases of external Bandar Lampung. It illustrates more corruption cases in the external of Bandar Lampung, far from the Corruption Court PN IA Tanjungkarang. This condition is the reason for Idwin Saputra $^{23}$ as the Public Prosecutor (JPU) of the Bandar Lampung, who previously served at the Blambangan Attorney in Way Kanan. It is very necessary to reconstruct the existence of the Corruption Court in the regions because with the current conditions, the settlement of corruption cases from the outside of Bandar Lampung faces many obstacles, including (1) the same way of checking, there is no special treatment; (2) the period for case settlement with the same examination; (3) the distance to attend the witnesses, besides the high cost, it is also the risk to the elderly witnesses' condition.

The reasons above are acceptable considering the average time to the case settlement. The examination of corruption cases from outside Bandar Lampung is faster than cases from inside Bandar Lampung. From outside Bandar Lampung, the average time to be investigated a

\footnotetext{
${ }^{22}$ Muladi, Kapita Selekta Sistem Peradilan Pidana (Semarang: Badan Penerbit Universitas Diponegoro, 1995), 5 .

${ }^{23}$ Idwin Saputra is JPU of Attorney Bandar Lampung and also a student of the Law Doctoral Program Universitas Lampung. The research is questionnaire at October 5, 2019; the same opinion from the answer to the informant's questionnaire, Muhammad Rony as the Prosecutor for the Attorney East Lampung; resource person Tedi Nopriadi as Prosecutor at the Lampung Attorney General's Office; Resource persons Salman Alfarasi and Ahmad Baharuddin Naim as corruption judges at the Tanjung Karang District Court.
} 
corruption case is 93 (ninety-three) days, while from Bandar Lampung is 100 (one hundred) days, as illustrated in table 2 below.

Table 2: List of the length of time the Corruption Case Settlement in PN. Tanjung Karang in the $2014-2018$

\begin{tabular}{|l|c|c|c|c|c|c|}
\hline \multirow{2}{*}{ Location } & \multicolumn{5}{|c|}{ Year } & \multirow{2}{*}{ Average } \\
\cline { 2 - 6 } & 2014 & 2015 & 2016 & 2017 & 2018 & \\
\hline Bandar Lampung & 71 & 120 & 108 & 95 & 107 & 100 \\
\hline Luar Bandar Lpg & 95 & 95 & 105 & 89 & 81 & 93 \\
\hline Average & 83 & 107 & 106 & 92 & 94 & 96 \\
\hline
\end{tabular}

Source: PN Tjk data processed in 2019

During the 93 (ninety-three) days, according to Salman Alfarasi, corruption case settlement from outside the Bandar Lampung area was carried out on average 15 (fifteen) times since the initial trial until the decision was made. This illustrates that so many costs must be payablein addition to the workforce and time by a public prosecutor in a corruption case from outside Bandar Lampung.

If the data is further analyzed, it can be seen that the cause of the settlement period for corruption case by the IA Tanjung Karang Corruption Court from outside Bandar Lampung is faster than from inside Bandar Lampung. It is because of the judges' policy for every corruption case from outside Bandar Lampung in a far location and the difficulties in presenting the witnesses. According to the trial agenda, the examination of every corruption case from outside Bandar Lampung must be resolved every day even though it is late at night. Based on the judges' discretion, if the trial's agenda on that day is to hear the testimony of witnesses, all witnesses who the public prosecutor has presented must be examined by the panel of judges on that day.

The argument above is in accordance with the opinion of Baharuddin Naim. ${ }^{24}$ The method of handling corruption cases, both from the Bandar Lampung Attorney District and from outside Bandar Lampung, is the same. It is just from the Attorney outside Bandar Lampung, considering their location is far such from Liwa, Way Kanan. So on, the judges will take the policy until the time of the case arrives at the Tanjung Karang District Court. At that time, the case is still on trial until the last trial in the evening. The anticipation of this condition is the prosecutor usually arrives in Bandar Lampung the day before the trial day, and the defendant is detained at the Way Hui Prison. ${ }^{25}$

Meanwhile, the period for corruption case settlement from Bandar Lampung is longer, and to present witnesses relatively easy because they are located in Bandar Lampung. In general, cases filed by the Lampung High Prosecutor's Office are large corruption cases that require many witnesses. In the proof, so it takes a lot of time to solve.

Based on the data that viewed from an institutional point, the Corruption Court PN IA Tanjung Karang in eradicating corruption in Lampung Province can be effective considering the average settlement period for corruption case is less than 120 (one hundred and twenty) days. It is based on the provisions of Article 29 Corruption Court Law. ${ }^{26}$ According to the

\footnotetext{
${ }^{24}$ Nenny Dwi Ariani, "EFEKTIVITAS PENGADILAN TINDAK PIDANA KORUPSI DAERAH DALAM PEMBERANTASAN KORUPSI: STUDI DI PENGADILAN TINDAK PIDANA KORUPSI PADA PN KLAS IA TANJUNGKARANG”, Thesis, Universitas Lampung, (2013), 45.

25 Ibid

${ }^{26}$ M. S. Sawardi, "PELAKSANAAN ASAS PERADILAN CEPAT DALAM PERKARA TINDAK PIDANA KORUPSI (STUDI TERHADAP PENERAPAN PASAL 29 UNDANG-UNDANG NOMOR 46 TAHUN 2009 DI PENGADILAN TINDAK PIDANA KORUPSI PONTIANAK)", Jurnal Nestor Magister Hukum 2, no. 2 (2012): 1-18, 2.
} 
provisions of the article, corruption cases are examined, tried and judged by the Corruption Court at the first level within a maximum period of 120 (one hundred and twenty) working days from the date the case is transferred to the Corruption Criminal Court. However, if viewed from the quality of the decision, it is still doubtful considering how the examination was carried out by chasing time (catch-up). So, the examination of witnesses was not carried out comprehensively.

There was a corruption cases settlement by the Corruption Court PN IA Tanjung Karang for less than 120 (one hundred and twenty) days as determined by Article 29 of Law Number 46 of 2009 concerning the Corruption Court. To the existence of Standard Operating Procedures that have been established by the Corruption Court PN IA Tanjung Karang. According to Salman Alfarasi, when answering a research questionnaire about how the stages of the corruption case entry to the Tanjung Karang Corruption Court, the stages of transferring corruption case files to the Tanjung Karang District Court are carried out through the One-Stop Integrated Service (PTSP) system of the Tanjung Karang District Court. It is in accordance with the provisions of the Decree of the Director-General of Badilum No. 77 / DJU / SK / HM.02.3 / 2/2018 concerning Standard One-Stop Services Guidelines (PTSP) in High Courts and District Courts.

However, if viewed from the Corruption Court PN IA Tanjung Karang status as a corruption criminal justice system, it can be said that the operation of the Corruption Court PN Class IA Tanjung Karang is not effective. It is because of the court's location in Bandar Lampung, so every Public Prosecutor (JPU) will sue a case at the Corruption Court PN IA Tanjung Karang must come to Bandar Lampung one day before the Corruption Court PN IA Tanjung Karang tries that case. This condition causes the investigation and prosecution of other corruption cases as the prosecutor's responsibility to become neglected and take a long time.

The Corruption Court PN IA Tanjung Karang's ineffectiveness as a sub-system of corruption criminal justice can also be seen from the prosecutor's process from outside Bandar Lampung when presenting witnesses. For example, suppose the prosecutor from the Attorney Liwa District will present the witnesses at the Corruption Court PN IA Tanjung Karang, so the day before the trial. In that case, the witnesses must be in Bandar Lampung. The result of this condition is the prosecutor faced obstacles in bringing the witnesses together to Bandar Lampung. They also had to bear all the costs of transportation, lodging/hotels, and the witnesses' consumption for a minimum of two days and two nights, while the funds use the prosecutor's money first. Then, when it is finished, it will be replaced considering because the system of operational costs for corruption case uses the renumbers system.

The existence of complaints about the Regional Corruption Court recently is because of the decline in the Corruption Court's performance in the eyes of the community. In the beginning, the Corruption Court received public praise but now being scorned. Before established in some regions, the Corruption Court's performance only in Jakarta, and it always received appreciation. From 2004 to 2009, no less than 120 corruption defendants were processed by the Corruption Court, all of them were found guilty and sentenced to 3-4 years in prison. However, after Corruption Courts were established in some regions, the situation was reversed. One by one, the corruption defendants were acquitted. According to Indonesia Corruption Watch (ICW) records, in less than two years, 40 corruption case defendants have been acquitted by the regional corruption court. This phenomenon of acquittal made insecurity in many parties. Beside scorned by society, there is a discourse that the Corruption Court be dissolved. ${ }^{27}$

\footnotetext{
${ }^{27}$ Emerson Yuntho, "SIMALAKAMA PENGADILAN KORUPTOR”, Kompas Article, November16, (2011).
} 


\section{The Ideal Construction of Corruption Justice System to Support National Development}

The Corruption Court's existence is fundamental in eradicating corruption because besides increasing the efficiency and effectiveness of law enforcement against corruption, it is also based on the stage of examination in court. There is an evidence process according to the law and the judge to determine the defendant's guilt. So the defendant can be held responsible for the crime. Therefore, in the Corruption Court, the panel of judges' composition consists of 2 (two) District Court judges and 3 (three) ad hoc judges. ${ }^{28}$ This is because the judge's decision as a basis for punishing the defendant must be based on facts and circumstances as well as evidence obtained from the results of the examination in court. According to Mardjono Reksodiputro, the importance of the Corruption Court's existence is through the interpretation of Paragraph (1) Article 191 and Article 197 of the Criminal Procedure Code. ${ }^{29}$ It must be interpreted that the adjudication stage must be "dominant" in the entire judicial process because both in terms of acquittal and guilty verdicts, this must be based on "facts and circumstances as well as tools of evidence obtained from examination in court trial". ${ }^{30}$

The existence of the Regional Corruption Court, which is located in the capital province, has received criticism from the public because it is inefficient and ineffective in eradicating corruption. Therefore, the formulation policy regarding the establishment of the Regional Corruption Court needs to be evaluated so that the existence can encourage national development goals. The reconstruction of the existence of the Regional Corruption Court includes the competence, place of domicile, and the way the judges work.

The relative competency aspect of the Regional Corruption Court should not be limited by the province administrative area. The Republic of Indonesia's administrative area consists of various Provinces and Regencies/Cities. In these conditions, the relative competence of a Corruption Court can also examine corruption cases that occur in districts/cities close to the Corruption Court even though they are located in a different province from the domicile of a Corruption Court. For example, a corruption case occurred in West Lampung (Liwa) should be tried at the PN Corruption Court Bengkulu because it is closer to the PN Corruption Court Tanjungkarang. Therefore, a Tipikor judge can be employed in more than one Corruption Court.

In addition, it can also use a zoning system, for example, the area of Lampung Province is divided into three zonings, including (1) South Zoning covering Bandar Lampung City, South Lampung Regency, Pesawaran Regency, Pringsewu Regency, and Tanggamus Regency, where the trial is at Tanjungkarang District Court; (2) The Central Zoning covers Central Lampung Regency, Metro City and East Lampung Regency, and the trial is in Gunung Sugih District Court; (3) The North Zoning includes North Lampung Regency, West Tulang Bawang Regency, Menggala Regency, Mesuji Regency, Way Kanan Regency, West Lampung Regency, and Pesisir Selatan Regency where the trial is in Kotabumi District Court. The existence of a model for examining corruption cases, as mentioned above, will save the cost of examining corruption cases, which means it can save state expenditure,and it can be used for national development.

The argument mentioned above is considering the high cost of handling a corruption case. ${ }^{31}$ The details of the expenses allocated to each law enforcement agency are not the same. For example, in Attorney, the total cost of a corruption case is 200 million rupiahs. The

\footnotetext{
${ }^{28}$ General Explanation of Law Number 46 of 2009 concerning Corruption Court.

${ }^{29}$ Sandro Unas, "KAJIAN YURIDIS TERHADAP BENTUK PUTUSAN HAKIM DALAM TINDAK PIDANA KORUPSI," Lex Et Societatis 7, no. 4 (2019): 58-65, 59 \& 63.

${ }^{30}$ Mardjono Reksodiputro, Hak Asasi Manusia Dalam Sistem Peradilan Pidana (Jakarta: Pusat Pelayanan Keadilan dan Pengabdian Hukum (d/h Lembaga Kriminologi) UI, 1994), 34.

${ }^{31}$ https://www.hukumonline.com/, accessed on March 3, 2021.
} 
details are 25 million for the investigation stage, 50 million for the investigation stage next level, 100 million for prosecution stages. Twenty-five million left will be used for the verdict executing cost. At the Police, the costs of corruption cases investigation are not much different; it is Rp208 million per case. Meanwhile, the cost of handling cases by the Corruption Eradication Commission (KPK) according to Asrul Sani, Member of Commission III of the DPR at the 2018 Budget Discussion Meeting for the KPK, namely Rp. 11.08 billion for the 100 cases in the investigation were submitted. Prosecutions and executions for 95 cases are Rp. 18,825 billion. If we are on average, I consider 100 cases. The cost of handling corruption cases at the KPK, starting from investigations, prosecutions to execution, is at least IDR 433 million per case. ${ }^{32}$ Meanwhile, if it is compared with the amount of state revenue from the penalty for recovering state losses, it is relatively tiny, as an example illustrated in table 3 below.

Table 3: List of Total Refunds of State Finances by Decisions of Corruption Eradication Judges at the Tanjung Karang District Court in 2014-2018.

\begin{tabular}{|c|c|c|c|}
\hline Year & Total of Cases & $\begin{array}{c}\text { Total Returns of State Losses } \\
(\mathrm{Rp})\end{array}$ & $\begin{array}{c}\text { Average } \\
(\mathrm{Rp})\end{array}$ \\
\hline 2014 & 73 & 17.170 .311 .758 & 235.209 .750 \\
\hline 2015 & 64 & 16.429 .069 .268 & 256.704 .207 \\
\hline 2016 & 54 & 19.182 .887 .805 & 355.238 .663 \\
\hline 2017 & 65 & 23.067 .428 .680 & 354.883 .518 \\
\hline 2018 & 49 & 6.539 .358 .495 & 133.456 .295 \\
\hline Average & 305 & 82.389 .056 .000 & $\mathbf{2 7 0 . 1 2 8 . 0 5 2}$ \\
\hline
\end{tabular}

Source: Processed Data 2019

Based on the data in table 3 above, it is known that the number of funds for the return of state losses due to corruption through the Corruption Judge's Decision at the Tanjungkarang District Court in 2014 was IDR 17.170.311.758 (seventeen billion one hundred seventy million three hundred eleven thousand seven hundred and fifty-eight rupiah)as the return for 73 (seventy-three) cases. Each case's average count is IDR 235.209.750 - (two hundred thirtyfive million two hundred nine thousand seven hundred and fifty rupiahs). In 2015 amounting to Rp 16,429,069,268 (sixteen billion four hundred twenty-nine million sixty-nine thousand two hundred and sixty-eight rupiahs) as a refund for 64 (sixty-four) cases, so the average for each case is Rp. 256,704,207 - (two hundred and fifty-six million seven hundred four thousand two hundred and seven rupiahs). In 2016, Rp 19,182,887,805 (nineteen billion one hundred eighty-two million eight hundred eighty-seven thousand eight hundred and five rupiahs) as a refund for 54 (fifty-four) cases, so the average for each case is Rp. 355,238,663, - (three hundred and fifty-five million two hundred thirty-eight thousand six hundred and sixty-three rupiah).

In 2017, Rp 23,067,428,680, - (twenty-three billion sixty-seven million four hundred twenty-eight thousand six hundred and eighty rupiah) as a return for 65 (sixty-five) cases, so the average for each case is Rp. 354,883,518, - (three hundred and fifty-four million eight hundred eighty-three thousand five hundred and eighteen rupiahs). In 2018, Rp $6,539,358,495$, - (six billion five hundred thirty-nine million three hundred fifty-eight thousand four hundred and ninety-five rupiah) as a refund for 49 (forty-nine) cases, so the average calculation for each case is Rp. 133,456,295, - (one hundred thirty-three million four hundred and fifty-six thousand two hundred and ninety-five rupiah). The average return on state losses due to corruption based on the Decision of the Corruption Eradication Judge of

\footnotetext{
32 https://news.detik.com/berita/3650543/, accessed on October 9, 2019.
} 
the Tanjungkarang District Court for 5 (five) years from 2014 to 2018 is IDR 82,389,056,000, - (eighty-two billion three hundred eighty-nine million and fifty-six thousand rupiah) from as many as 305 (three hundred five) cases. It means for each case amounting to IDR 270,128,052, - (two hundred seventy million one hundred twenty-eight thousand and fifty-two rupiah).

Ideally, in the context of supporting national development in law enforcement activities against corruption cases should not make the state "losses" because the amount of costs for handling the cases is far more significant than the number of funds returned to the state due to corruption. Therefore, it is necessary to consider a model for handling corruption through the criminal justice system's mechanism and to develop a case handling model in the framework of Restorative Justice, namely for corruption with a nominal amount is below 1 (one) billion. It is enough to refund the state's losses, and for the government who did the corruption will punish the administrative sanctions. Meanwhile, the corruption with an amount of more than 1 (one) billion is resolved through the corruption criminal justice system mechanism. Returning state losses not only use equal corrupted money but also count the perpetrator's profits by using corruption money.

Besides the reasons above, it seems the current corruption eradication model through the Criminal Justice System mechanism is more burdensome state finances than to restore state losses due to corruption for national finance development. It can be seen from the data in the Tanjungkarang Tipikor Court, in the last five years, from 2014 to 2018 is more than 300 cases tried by the Tanjungkarang Corruption Court were sentenced to light imprisonment between one to two years. The use of imprisonment will add to the state's burden and increase the detention room because the existing detention room is no longer able to accommodate prisoners. It will also increase the state expenditure for prisoners' consumption costs in 2019 is budgeted at 1.79 trillion. It can be seen from the statement of the Minister of Law and Human Rights (Menkumham) Yasonna Laoly that the fund for prisoners food in 2019 is 1.79 trillion is a significant increase.

The cause of the food cost increase is the increasing number of prisoners, the Correctional Institutions (Lapas) and detention centres' capacity. "2019 to 1.79 trillion is a big jump because there are additional prisoners. According to the area, an average of Rp.20,000 per prisoner each day," said Yasonna at the Kemenkumham Building, Jakarta, Thursday (27/12/2018). It was referring to data from the Ministry of Law and Human Rights, the cost of meals for prisoners in $2017 .{ }^{33}$ Therefore, it is necessary to have the perspective and work of law enforcement officers, especially judges, when imposing light imprisonment to eradicate corruption. In other words, the use of the imprisonment instrument must be carried out carefully. If it is deemed the use of imprisonment is better for the state interests and the defendant, so the imprisonment must be for a long period. However, if it is considered without the application of imprisonment, corruption eradication goals can be realized, then light imprisonment does not use in every decision.

Based on the arguments, it is appropriate for a change in the politics of law in tackling corruption crimes through the current mechanism of the criminal justice system in Indonesia to support national development. The construction of tackling corruption crimes as offered above has also been by the principles of criminal individualization applied by most countries in the world and at the same time answering the current political law in the form of solving criminal cases through the principle of Restorative Justice. ${ }^{34}$ In addition, there is a different

\footnotetext{
33 https://nasional.kompas.com/read/2018/12/27/15413471/jumlah-napi-bertambah-biaya-makan-capai-rp-17triliun, accessed on August 17, 2019.

34 Fuzi Narindrani, "PENYELESAIAN KORUPSI DENGAN MENGGUNAKAN RESTORATIF JUSTICE (CORRUPTION SETTLEMENT USING JUSTICE RESTORATIVES)," Jurnal Penelitian Hukum De Jure 20, no. 4 (2020): 5-11, 5, DOI: 10.30641/dejure.2020.V20.605-617.
} 
treatment of corruption cases with small nominal state losses in accordance with changes in the legal politics of tackling corruption crimes as adopted by Law Number 20 of 2001 concerning Amendments to Law Number 31 of 1999 concerning Corruption Eradication. According to the General Explanation of the Corruption Eradication regulates new provisions regarding the maximum imprisonment and fines for corruption is less than Rp.5.000.000.00 (five million rupiahs). This provision is intended to eliminate the sense of injustice for corruption perpetrators if the value corrupted is relatively small.

\section{Conclusion}

The current efforts to eradicate corruption have not brought significant changes. Corruption cases still occur in many government agencies, both central and regional, including in the judiciary. The existence of a policy in reforming the criminal law of corruption from Law Number 3 of 1971 and replaced by Law Number 31 of 1999 as the basis for the establishment of the Corruption Court has not supported efforts to eradicate corruption in the context of national development. One of the reasons is the Regional Corruption Court's existence as seen as ineffective and inefficient in corruption eradication. Therefore, it is deemed important to reconstruct the Corruption Justice System in Indonesia through a policy to reduce the costs in handling corruption cases on the one hand and increasing the return financial losses state to support national development.

The ideal construction of the corruption court system is to support National Development, namely the Regional Corruption Court's relative competence, which is not limited by the administrative area. The Republic of Indonesia's administrative area consists of various Provinces and Regencies/Cities. In these conditions, ideally, the relative competence of a Corruption Court can also examine corruption cases in districts/cities which close to the Corruption Court, even though they are located in a different province from the domicile of a Corruption Court. For example, a corruption case in West Lampung (Liwa) was tried in the Corruption Court at the PN. Bengkulu because it is closer to the Corruption CourtPN Tanjungkarang. Therefore, a judge at the Tipikor Court can be employed in more than one Corruption Court. In addition, the operation of the Regional Corruption Court is using the Zoning System (a division of regions), for example, the Lampung Province is divided into three zonings including (1) South Zoning includes Bandar Lampung City, South Lampung Regency, Pesawaran Regency, Pringsewu Regency, and Tanggamus Regency where the trial at the Tanjungkarang District Court; (2) the Central Zoning includes Central Lampung Regency, Metro City and East Lampung Regency where the trial is at Gunung Sugih District Court; (3) The North Zoning includes North Lampung Regency, West Tulang Bawang Regency, Menggala Regency, Mesuji Regency, Way Kanan Regency, West Lampung Regency, and Pesisir Selatan Regency where the trial is at Kotabumi District Court. The existence of a model for examining corruption cases like this will save the cost of examining corruption cases, which means saving state expenditure to support national development.

\section{Recommendations}

To immediately reconstruct the corrupt justice system by changing the provisions on the relative competence of the Regional Corruption Court; In order to immediately take implement the Zoning policy for Corruption Case Investigation by the Regional Corruption Court. 


\section{A. Journal}

\section{REFERENCES}

Afif, Muhammad. "EKSISTENSI PENGADILAN TINDAK PIDANA KORUPSI DI INDONESIA DALAM PENEGAKAN HUKUM TINDAK PIDANA KORUPSI DI INDONESIA", Ensiklopedia of Journal 1, no. 1, 2018: 97-106, 103.

Fitriati. "ANALISIS PERKEMBANGAN SISTEM PERADILAN PIDANA DITINJAU DARI PERSPEKTIF PENGADILAN TINDAK PIDANA KORUPSI," Yustisia Jurnal Hukum 3, no. 3, 2019: 73-81, DOI: 10.20961/YUSTISIA.V3I3.29550.

Ifrani, et al., "TINDAK PIDANA KORUPSI SEBAGAI KEJAHATAN LUAR BIASA," AlAdl: Jurnal Hukum 3, no. 3, 2017: 319-36, DOI: http://dx.doi.org/10.31602/aladl.v9i3.1047.

Mauliddar, Nur., Din, Mohd., Rinaldi, Yanis. "GRATIFIKASI SEBAGAI TINDAK PIDANA KORUPSI TERKAIT ADANYA LAPORAN PENERIMA GRATIFIKASI," Kanun Jurnal Ilmu Hukum 19, no. 1, 2017: 155-173.

Mudzzakir. "PENGADILAN TINDAK PIDANA KORUPSI: TINDAK PIDANA BIASA PENANGANANNYA LUAR BIASA (CORRUPTION COURT: COMMON CRIME WITH EXTRAORDINARY REDUCTION)", Jurnal Legislasi Indonesia 8, no. 2, 2011: 297-320.

Narindrani, Fuzi. "PENYELESAIAN KORUPSI DENGAN MENGGUNAKAN RESTORATIF JUSTICE (Corruption Settlement Using Justice Restoratives)," Jurnal Penelitian Hukum De Jure Direvisi 20, no. 4, 2020: 5-11, DOI: 10.30641/dejure.2020.V20.605-617.

Nazriyah, R. "KEWENANGAN KOMISI PEMBERANTASAN KORUPSI DALAM PENYIDIKAN KASUS SIMOLATOR SIM (KAPOLRI VS KPK)," Jurnal Hukum IUS QUIA IUSTUM 19, no. 4, 2012:586-606.

Nurdin, H. "EKSISTENSI HAKIM AD HOC PADA PENGADILAN TINDAK PIDANA KORUPSI DALAM SISTEM KEKUSAAN KEHAKIMAN.” Meraja Journal 2, no. 2, 2019: 167-83, DOI: 10.33080/mrj.v2i2.57.

Rahmadan, Davit., Fakhrur Razi, Sulaiman. "EFEKTIFITAS PERADILAN TINDAK PIDANA KORUPSI DALAM PEMBERANTASAN KORUPSI DI PENGADILAN NEGERI PEKANBARU," Al Hurriyah : Jurnal Hukum Islam 2, no. 2, 2017: 137-148, DOI : 10.30983/alhurriyah.v2i2.409.

Safii, Imron. "URGENSI PENGADILAN TINDAK PIDANA KORUPSI DALAM MEWUJUDKAN PERADILAN YANG BERSIH DAN BERWIBAWA," Pandecta: Research Law Journal 9, no. 1, 2014: 76-91, DOI: 10.15294/pandecta.v9i1.2999.

Sawardi, M. S. "PELAKSANAAN ASAS PERADILAN CEPAT DALAM PERKARA TINDAK PIDANA KORUPSI (STUDI TERHADAP PENERAPAN PASAL 29 UNDANG-UNDANG NOMOR 46 TAHUN 2009 DI PENGADILAN TINDAK PIDANA KORUPSI PONTIANAK)." Jurnal Nestor Magister Hukum 2, no. 2, 2012: $1-18$

Sihotang, Nia S. "PENERAPAN ASAS SEDERHANA, CEPAT DAN BIAYA RINGAN DI PENGADILAN NEGERI PEKANBARU BERDASARKAN UNDANG-UNDANG NOMOR 48 TAHUN 2009 TENTANG KEKUASAAN KEHAKIMAN." Jurnal Online Mahasiswa Fakultas Hukum Universitas Riau 3, no. 2, 2016: 1-15.

Sina, La. "DAMPAK DAN UPAYA PEMBERANTASAN SERTA PENGAWASAN KORUPSI DI INDONESIA,” Jurnal Hukum Pro Justitia 26, no. 1, 2008: 39-51.

Tiku, Imanuel Arung. "KAJIAN YURIDIS TERHADAP TINDAK PIDANA KORUPSI," LEX CRIMEN 9, no. 2, 2020: 1-20.

Unas, Sandro. "KAJIAN YURIDIS TERHADAP BENTUK PUTUSAN HAKIM DALAM TINDAK PIDANA KORUPSI.” LEX ET SOCIETATIS 7, no. 4, 2019: 58-65. 
Widiastuti, T. W. Tri "KORUPSI DAN UPAYA PEMBERANTASANNYA," Jurnal Wacana Hukum 8, no. 2, 2009: 107-118, DOI: 10.33061/1.JWH.2009.8.2.317.

\section{B. Book}

Maroni, 2011. Pemberantasan Korupsi Berbasis Hukum Pidana Progresif. Universitas Lampung. Bandar Lampung.

Muladi. Kapita Selekta Sistem Peradilan Pidana. Semarang: Badan Penerbit Universitas Diponegoro, 1995.

Reksodiputro, Mardjono. Hak Asasi Manusia Dalam Sistem Peradilan Pidana. Jakarta: Pusat Pelayanan Keadilan dan Pengabdian Hukum (d/h Lembaga Kriminologi) UI, 1994.

\section{Thesis, Article, and Internet}

Emerson Yuntho, "SIMALAKAMA PENGADILAN KORUPTOR", Kompas Article, November16, 2011.

https://nasional.kompas.com/read/2018/12/27/15413471/jumlah-napi-bertambah-biayamakan-capai-rp-17-triliun, accessed on August 17, 2019.

https://news.detik.com/berita/3650543/, accessed on October 9, 2019.

Nenny Dwi Ariani, "EFEKTIVITAS PENGADILAN TINDAK PIDANA KORUPSI DAERAH DALAM PEMBERANTASAN KORUPSI: STUDI DI PENGADILAN TINDAK PIDANA KORUPSI PADA PN KLAS IA TANJUNGKARANG”, Thesis, Universitas Lampung, 2013.

www.beritasatu.com/hukum/101558-dua-tahun-pengadilan-tipikor-daerah-tren-vonis-ringanmeningkat.html, accessed on May 16. 2020. 
